\title{
IB Times: Muhammadiyah Younger Generation's Adaptation to New Media Usage in The Digital Era
}

\author{
Filosa Gita Sukmono ${ }^{1}$, Fajar Junaedi ${ }^{2}$ \\ \{filosa@umy.ac.id ${ }^{1}$, fajarjun@umy.ac.id ${ }^{2}$ \} \\ Universitas Muhammadiyah Yogyakarta, Jl. Brawijaya, Geblagan, Tamantirto, Kec. Kasihan, Bantul, \\ Daerah Istimewa Yogyakarta ${ }^{1,2}$
}

\begin{abstract}
Muhammadiyah is the most significant modern Islamic organization in Indonesia. As a modern organization, Muhammadiyah has realized the importance of mass media. This awareness is marked by the publication of Suara Muhammadiyah magazine, which has been published for more than 100 years. This magazine is recognized as the oldest Islamic magazine in Indonesia that is still disseminated. Unfortunately, when entering the digital era, Muhammadiyah did not react as quick as in the print media. Realizing Muhammadiyah's travails in facing the digital age, a group of young Muhammadiyah took an initiative to publish online digital media so-called the IB Times. Against the background, this research aims to explore how the IB Times editorial policies deal with new patterns in media diet. This research found that the IB Times is different from Muhammadiyah's previous digital media. The IB Times is not only for Muhammadiyah members but also to reach wider audiences. The writing style in the IB Times is designed for young digital readers.
\end{abstract}

Keywords: IB Times, Muhammadiyah, Digital, Media, Young Generation.

\section{Introduction}

Since its establishment, Muhammadiyah as modern and progressive Islamic organization has strongly realized the importance of media. Suara Muhammadiyah magazine, Muhammadiyah's official publication since 1915, is the proof. Muhammadiyah as an organization was founded since 1912. That is to say, only within a three-year gap, the elites of this first Indonesian modern Islamic organization considered media to be one of their vital movements.

However, Muhammadiyah faces print media and digital media differently. As regards print media, Muhammadiyah quickly adapted to the condition, as what they showed with the publication of Suara Muhammadiyah. Nevertheless, when it came to digital media, Muhammadiyah did not manage it as fast as before. Muhammadiyah's website has left behind by other Islamic websites in terms of popularity.

Regarding digital media, clearly, younger generations play a significant role within it. Coupled with the development of social media, this group has become increasingly active in digital media to voice their ideas. Today's younger people were mostly raised in the era of smartphone and other cutting-edge technologies. Their complaints about the speed of wifi connection and price of cellular data have grown to be epidemic and can be seen as a sign of their entanglement. According to BBC Newsround in 2016 (9 February), most of the current 
adolescents are social media user since they were ten years old. It is not surprising if those teenagers are seriously deemed potential targets by many stakeholders because numerous essential transformations from childhood to adulthood take place in this phase. It is a stage where an individual learns about and admit himself. It is critical considering media owns the capability to alter human's interaction pattern and even social changes [1]. Unfortunately, Muhammadiyah has not provided appropriate amount of concern to their younger generations, notably in this issue.

In the midst of Muhammadiyah's lack of heed to their younger members, who are actively using digital media, a progressive Islamic website called IB Times ('I' stands for Islam, and 'B' stand for berkemajuan [progressive]) (https://ibtimes.id), showed up in 2018 as a result of the ideas of Muhammadiyah's younger generations. This article will demonstrate how digital media managed by Muhammadiyah's younger members works and how Muhammadiyah and their more youthful people adapt to recent technological transformation. Research of this topic has been conducted by several researchers [2],[5]. However, none of the mentioned above has studied the relation between Muhammadiyah, youngsters, and digital media.

\section{Research Method}

The research applied a case-study as the method, and it is carried out with these following steps by data collection and reduction. The data collection was performed with in-depth interviews, observation, and literature review. The interview here was conducted in flexible, informal, and open ways, without rigorous structure, and able to be repeated to the informant. The questions were arranged with an interview guide, and the lists was the priority in the interview process. After that, the guidance could be expanded, developed, and modified for gaining more in-depth and unpredicted information. For accuracy, the answers were written down [6][6]. The informants were chosen with a purposive sampling method and a criterionbased election. In this research, the informants were the editors of IB Times. The results were recorded in the field note. The literature review was conducted by analyzing various works of literature regarding media management and Muhammadiyah citizen journalism.

The data reduction in the research was a part of the selection, simplification, and abstraction process of the data taken from the interview record and field note. The data display was considered as a cog of the organizational information and description in the form of narration to enable the research conclusion could be finished although the outcome needs to be verified to make the report adequately reliable as well. In that case, specific repetitions were necessary for ensuring and tracking down the result in the appropriate way. Verification could also be carried out by replicating the other data developing the exactitudes so that the conclusion could be stronger and entrusted [7].

\section{Result and Discussion}

IB Times emerged as a response of Muhammadiyah's younger members towards a new tendency, a transformation that was affected by digital media toward the blueprint of media and audiences. IB is an abbreviation from Progressive Islam (Islam Berkemajuan), a phrase referring 
to Muhammadiyah's ideology, meaning that Islam is a religion that contains progressive values to develop an eminent civilization and be a blessing for all creatures (Din al-Hadlarah).

IB Times endeavors to present Islam culturally from the perspective of Muhammadiyah; hopefully, it can be accepted by Indonesian younger people. IB Times's concern is the younger people who actively use social media. In the website, IB Times declared that "in the millennial age, changes in the informational access pattern have transformed social sets of attitudes, behaviors, and activities. There are four social media characteristics that influence the complexion of millennial society. firstly, it is real-time. In a matter of second, information can be uploaded and posted. Secondly, it is interactive. All figures could be commented without mediation or editorial process. Thirdly, it is documentative. Anything that has been posted is well-documented. Finally, it is accumulative because media managers might be the journalist, editor, editor in chief, and distributor concurrently.

IB Times' editor in chief, Azaki Khoirudin, asserted that IB Times started from an internet site called "Progressive Islam" (Islam Berkemajuan). The name was changed to be easier to remember and recognize by younger people. The name Progressive Islam was chosen because the ones who run the site were Muhammadiyah's youngsters.

Zaki Khoirudin realized that Muhammadiyah was left behind as opposed to other Islamic organization in terms of digital media usage in terms of information dissemination. Radical Islamic organizations, for example, has actively used digital media to voice their interest, as well as to recruit new members, far before the IB Times.

As for the code of ethics, the standard code of ethics of journalism become the operational foundation for this multi-platform journalist to produce news, articles, photos, infographics, graphic movement, and so on. On the other hand, Islamic code of ethics of journalism, referring to 'fiqh' information is the operational foundation for deciding topic or content so as not to violate moderate Islam principle (Wasathiyah), which is a reflection of al-Qur'an values (alnash), science and technology development, and Indonesian local wisdom.

Before IB Times, Muhammadiyah's digital media tended to be like informational sites to inform official organization activities. Two sites represent Muhammadiyah officially: the website of Muhammadiyah Central Board (Pimpinan Pusat Muhammadiyah) in www.muhammadiyah.or.id and The Voice of Muhammadiyah Magazine (Suara Muhammadiyah) in www.suaramuhammadiyah.id. Those two sites mostly contain hard news on activities performed by Muhammadiyah as an organization. Although some articles that present Muhammadiyah's ideas do occur, the number is limited. Not to mention that the writing style also uses print media approach.

Different from other digital media organized by Muhammadiyah, IB Times present novelty in digital media management, whether towards the content or management. Regarding the content, IB Times presents articles about ideas and features. Articles on ideas that is written in IB Times are displayed using a popular style of writing. The reason behind this is that Progressive Islam that is voiced by Muhammadiyah is a grand narrative. Consequently, it is difficult to be grasped by the audience, especially the younger generation. IB Times management contended that notions concerning progressive Islam should be displayed using an approach that is suitable for digital audiences. It is because this segment is the group that uses media actively. Viewers in this segment participate in internet's connectivity, reactivity, and interactivity.

Regarding connectivity, reactivity, and interactivity, Rafaeli distinguished the functions of each. The network should have humans interface, but also they should have architects that enable that to happen. That type of interactive system, after rendered, might take its history, and through that kind of history, connectivity formed. Two-Way communication cannot solely 
guarantee interactivity. By contrast, exchanges or action-reaction should grow to be a relationship where one utterance turns to be a context for the other. Without this connectivity, the relation can be circular or solipsistic [8].

As the largest moderate Muslim organization, Muhammadiyah faces new challenges after the reformation, namely change in the political terrain and the rise of the new millennial generation, a digital generation who use digital media.

Muhammadiyah, as a modern Islamic organization, actually has realized, from the beginning, the importance of mass media. Muhammadiyah published the Suara Muhammadiyah magazine since the outset of this organization. Unfortunately, the circulation of Suara Muhammadiyah magazine was only internal to members of Muhammadiyah.

When various radical Islamic movements in the post-New Order era actively used digital media and social media as a mean of campaigning to gain publicity, Muhammadiyah seemingly did not realize the importance of using digital media. This can be seen from Muhammadiyah's digital media that is not well-managed in the early post-New Order era. Even until the beginning of the 2010s, digital media affiliated with Muhammadiyah did not enrich much public discourse.

Awareness to use digital media as media propaganda emerged in the mid-2010s. This is marked by a more professional media management from the official Muhammadiyah website, a digital version of the Suara Muhammadiyah magazine in a website format, and the publication of an internet site managed by several regional administrators of the Muhammadiyah region, such as in East Java province.

Judging from its editorial background, the IB Times is different from other digital media managed by Muhammadiyah. The IB Times is operated by the young generation of Muhammadiyah. They are millennials who actively interact with digital media. The format of the media they consume since they first interacted with mass media was digital media.

This background allows the IB Times editors to design editorial policies that are appropriate for the segmentation of their readers. The IB Times reader segmentation is millennial youth. IB Times editorial policies are designed for the readers. IB Times present essay and feature formats, not a hard news format.

As mentioned earlier, digital media and young people are characterized by connectivity, reactivity, and interactivity. These three elements can be seen from the contents of the IB Times. To build connectivity, reactivity, and interactivity, the IB Times presents its content according to the younger reader segment.

The challenge facing the IB Times is the availability of manuscripts that are ready to be published in the IB Times. Different from pwmu.co, a news website managed by Muhammadiyah management in East Java province, the IB Times has not developed many citizens journalism activity. Pwmu.co actively involves members of Muhammadiyah in East Java province as citizen journalists. The editor of pwmu.co actively conducts journalistic training for Muhammadiyah members. Muhammadiyah members who have been trained in journalism by the editor of pwmu.co are asked to write news about the activities of Muhammadiyah and send it to the editor of pwmu.co.

As a recommendation for the IB Times, the editors of the IB Times can utilize the User Generated Content (UGC) technology platform. Through the UGC platform, IB Times readers can also be contributors to fill IB Times content. UGC can actually be called the development of citizen journalism through blogging. Blogging is a practice of citizen journalism in which there is no curation, review, and editing process by the editor. In the UGC platform, articles from readers are reviewed by editors before being published on the website. In other words, UGC is a content that is produced by the users themselves. 
This method has been embarked quite a long time ago, and recently many popular sites have relied on UGC to be an up-to-date site. The site owners, therefore, only makes improvements or changes that are considered necessary. When information updates and all interactions on the website come from the active participation of its users, people may continuously interested in visiting the website.

This term actually began to be heard in around 2005 when people could access or update media and publications through new technologies, such as digital video, blogging, photos from smartphones, and wikis. Site users can begin to upload, develop, and even control their own content according to their wishes.

Over time, internet users are now not interested in interacting sites that have platforms, such as blogs or videos, except YouTube. Audiences are more interested in places where they can focused on talking about their own networks and only need a little time to update information. This is the reason of Micro UGC. The use of UGC can be considered by IB Times editors in the future to get more content and build more excellent connectivity, reactivity, and interactivity with their audience.

\section{Conclusion}

IB Times is an adaptation executed by Muhammadiyah toward the development of digital media technology. Organized by Muhammadiyah younger members, IB times displays information using connectivity, reactivity, and interactivity approaches. Regarding contents, IB times includes ideas and feature article, which is an implementation of progressive Islamic principle. By carrying moderate notions, IB Times is an answer to public concern regarding the spread of radical sites and social media accounts.

IB Times is a more sophisticated step initiated by younger Muhammadiyah's member to cope with the digital era. IB Times succeeds in connecting with the younger generations by presenting articles that are easier to understand by them. It is the critical factor making IB Times could interact with younger generations. The research recommends that digital media organized by Muhammadiyah could learn from IB Times in finding the way to approach digital audiences. It does not say that total imitation is necessary. The emphasis is in the capability to adjust with audiences and digital world's development, and Muhammadiyah's digital media ought to execute it effectively.

\section{Acknowledgement}

The authors would like to show their gratitude to Universitas Muhammadiyah Yogyakarta that supports this research and IB Times that allows the authors to conduct interviews.

\section{References}

[1] Nagib, N A M.: The Effects of Vlogging (Video Blogging) towards Female Teens' Sense of Beauty in Indonesia, dalam New Media in Disruption Era: A Challenge for Communication Research, Media and Multiculturalism, Yogyakarta, hlm. 61-70 (2018)

[2] Yustitia, S.: Citizen Journalism Melawan Mainstream Media, The Messenger, Vol. 2, no. 1, hlm. 19 (2016) 
[3] Sukmono, F G.: Ruang Publik Alternatif dalam Cyberspace, Komunikasi. Makna, Vol. 2, no. 2, hlm. 132-139 (2012)

[4] Zaenudin, H. N.: Cermin Citizen Journalism di Indonesia," Observasi, Vol. 10, no. 2, hlm. 103-114 (2012)

[5] Nasrullah.: Komodifikasi Warga Dalam Ruang Citizen Journalism, Kawista, Vol. 2, no. 2, hlm. 105224 (2012)

[6] Neuman, L.: Social Research Methods: Qualitative and Quantitative Approaches, 4th Edition. Boston: Allyn and Bacon (2000)

[7] Sutopo, HB Metode Penelitian Sosial Kualitatif. Solo: UNS Press (2000)

[8] Stephen W Littlejohn.: Encyclopedia of Communication Theory. California: Sage, (2019) 